\title{
TMPRSS2/ETV4 Fusion Gene
}

National Cancer Institute

\section{Source}

National Cancer Institute. TMPRSS2/ETV4 Fusion Gene. NCI Thesaurus. Code C116015.

A fusion gene that results from a chromosomal translocation $\mathrm{t}(17 ; 21)(\mathrm{q} 21 ; \mathrm{q} 22)$ which fuses the 5' untranslated region of the TMPRSS2 gene upstream of exon 3 of the ETV4 gene. This rearrangement is associated with prostate carcinoma and androgendependent expression of this fusion gene results in overexpression of ETS translocation variant 4 protein activity. 